\title{
Suid-Afrika se kernkragprogram en toekomsvooruitsigte
}

Die inbedryfstelling van die eerste eenheid van die Koebergkernkragstasie het nie slegs 'n nuwe era in elektrisiteitsvoorsiening in Suid-Afrika ingelui nie, maar dit is ook die hoogtepunt van die kernnavorsings- en ontwikkelingsprogram wat in 1959 ' $n$ aanvang geneem het en wat daarop gemik was om SuidAfrika in staat te stel om ook hierdie energiebron tot sy beste voordeel te kan benut.

Suid-Afrika is dus nou in staat om albei sy inheemse energiebronne, naamlik uraan en steenkool, vir die ontwikkeling van elektrisiteit te benut.

Dit is interessant dat een van die twee hoofaanbevelings deur die Navorsingsadvieskomitee van die eertydse Raad op Atoomkrag in 1957 was dat 'n kernkragsentrale naby Kaapstad gebou moes word. Vanjaar, 29 jaar later, het die inbedryfstelling van Koeberg-1 hierdie aanbeveling in vervulling sien gaan.

Tans, 25 jaar na die goedkeuring van die Raad op Atoomkrag se navorsings- en ontwikkelingsprogram deur die Volksraad, beskik Suid-Afrika oor 'n volwaardige kernenergieprogram. Die AEK, met UKOR en KERNKOR (die eertydse RAK) as vol filiale, het gegroei uit ' $n$ relatiewe klein navorsings- en ontwikkelingsorganisasie in die vroeë sestigerjare tot 'n nywerheidsonderneming met 'n personeelsterkte van meer as 6000 , wat die plaaslike kernbedryf ten volle kan ondersteun.

Sy aktiwiteit behels bykans die hele kernbrandstofsiklus, vanaf die ontginning, ekstraksie, omsetting na $\mathrm{UF}_{6}$, en die verryking van ons uraan, tot die berging van radioaktiewe afval op die nuutaangekoopte afvalbergingsterrein in Noordwes-Kaapland.

Die AEK het hom ook ten doel gestel om die byvoordele wat kernenergie bied, byvoorbeeld op mediese, landboukundige, nywerheids- en navorsingsgebied, in Suid-Afrika te vestig. Ons dink aan die produksie en beskikbaarstelling van radioaktiewe isotope, bestralingsgeriewe vir die sterilisering van wegdoenbare mediese toerusting en vir die preservering van vars produkte. In die laasgenoemde twee gevalle is reeds twee nywerheidsaanlegte gevestig naas die geriewe wat op Pelindaba bestaan.

Wat die toekoms van kernenergie betref, glo ek dat die AEK sy ondernemings verder sal moet uitbrei om die volledige kernbrandstofsiklus te dek en om ook plaaslik die tegnologie te vestig om in 'n redelike mate die vervaardiging en konstruksie van kernkragstasies te kan onderneem. Die groei in kernelektrisiteitsontwikkeling sal hoofsaaklik afhang van die algehele groeikoers in die vraag na elektrisiteit. Dit is wel so dat die beperkte waterbronne in die OosTransvaal, waar bykans al die elektrisiteit vir SuidAfrika opgewek word, en die skaarsheid aan groot steenkoolvelde om 'n $3600 \mathrm{MW}$-kragstasie vir 30 jaar van steenkool te voorsien, saam met ander faktore, daarop dui dat meer kragstasies aan die kus gevestig sal moet word om seewaterverkoeling te benut. Aangesien brandstofvervoerkoste in die geval van 'n kernkragstasie nietig is in vergelyking met dié van 'n steenkoolkragstasie ( 25 ton per jaar teenoor 3 miljoen ton per jaar vir 'n $1000 \mathrm{MW}(\mathrm{e})$-kragstasie), sal kernkragstasies aan die kus uit hierdie oogpunt alleen, bevoordeel word. Die algehele ontwikkelingskoste sal egter deurslaggewend wees, en dit is moeilik om te voorspel wat die werklike groeikoers van kernkragkapasiteit gaan wees. As ons aanvaar dat die geïnstalleerde vermoë van kernkragstasies teen dieselfde tempo sal groei as die elektrisiteitsaanvraag, kan daar verwag word dat dit ten minste op $8 \%$ van die totaal, (tans $1850 \mathrm{MW}(\mathrm{e})$ ), sal bly en dus moontlik teen 1995 sal verdubbel tot $-3600 \mathrm{MW}(\mathrm{e})$.

Suid-Afrika se behoefte om ook kernenergie aan te wend om by te dra tot die land se elektrisiteitsvraag word verder beklemtoon deur die rol van die petrochemiese nywerheid waardeur ons beskikbare steenkoolreserwes ' $n$ betekenisfaktor van 'n heel ander omvang kry.

Elektrisiteit bly die lewegewende bloed in die nywerheidsare van enige ontwikkelde land en dit is met trots dat Suid-Afrika se kernbedryf sy rol op dié gebied kan speel.

J.W.L. de Villiers 